\title{
REGRESSIVE CHANGES IN THE SUPERFICIAL LAYER OF HUMAN ARTICULAR CARTILAGE
}

\author{
BY \\ G. MEACHIM, F. N. GHADIALLY, AND D. H. COLLINS \\ Department of Pathology, University of Sheffield
}

By studying changes in the knee joint, Bennett, Waine, and Bauer (1942) were able to trace the development of osteo-arthritis. They showed that the condition initially affects the articular cartilage, a conclusion subsequently supported by Collins (1949). Osteo-arthritic fibrillation is the hallmark of the cartilage lesion. The fibrillated cartilage becomes soft and moist in texture. Chemical analysis shows it to be deficient in sulphated mucopolysaccharide (Matthews, 1953), and this depletion of mucopolysaccharide ground substance is reflected in a loss of matrix staining with toluidine blue in fibrillated areas (Collins and McElligott, 1960).

Fibrillation is at first confined to the superficial layer of the cartilage (Bennett and others, 1942; Collins, 1949). Subsequently it spreads more deeply, and, as it does so, the cartilage disintegrates until eventually the underlying bone is exposed. Subchondral bone changes, osteophyte formation, and capsular fibrosis are relatively late manifestations of the disease (Collins, 1949).

The present study was undertaken to determine if changes can be detected in the superficial layer of adult articular cartilage before the onset of actual fibrillation and also in order to study the early stages of fibrillation as seen under the light microscope. Juvenile articular cartilage has been taken as our standard of healthy intact cartilage. It is apparent that the superficial layer of non-fibrillated adult cartilage often shows regressive changes, with depletion of matrix ground substance and evidence of nuclear degeneration. Actual fibrillation seems to develop as an extension of this regressive change.

\section{Materials and Methods}

Samples of human articular cartilage were collected at necropsy from the central aspect of the head of the humerus and from near the articular edge of a femoral condyle. In addition, two samples of femoral articular cartilage were taken at operation before mid-thigh amputation.

Tissue for histology was prepared by excising a transverse block of cartilage from above the level of its calcified zone. By this method the need for preliminary decalcification is avoided, with improvement in the quality of subsequent metachromatic staining. The blocks were fixed in 4 per cent. formaldehyde in normal saline or formol-calcium.

The following staining methods were used:

(1) Toluidine blue (1 per cent. toluidine blue in distilled water diluted 1 in 10 in sodium acetatehydrochloric acid buffer at $p \mathbf{H} 4 \cdot 8$ ). Paraffinprocessed or frozen sections stained for 5 minutes, rinsed in distilled water, blotted, and taken straight to xylol.

(2) Ehrlich's haematoxylin and eosin on paraffin sections.

\section{Results}

Matrix Depletion

Toluidine blue staining of sections of juvenile samples of articular cartilage taken from the head of the humerus in babies and children shows matrix metachromasia extending virtually to the articular surface (Fig. 1).

Mucopolysaccharide depletion in the matrix of adult cartilage has been judged not only by loss of metachromasia but also by the diminution or complete loss of any form of colour reaction with toluidine blue.

Many of the adult samples from persons ranging in age from 28 to 82 years show areas where there is evidence of ground substance depletion in the matrix of the superficial layer and yet no fibrillation (Figs 2 to 5). In its least developed form the reduction or absence of matrix staining with toluidine blue is confined to a narrow band of cartilage 


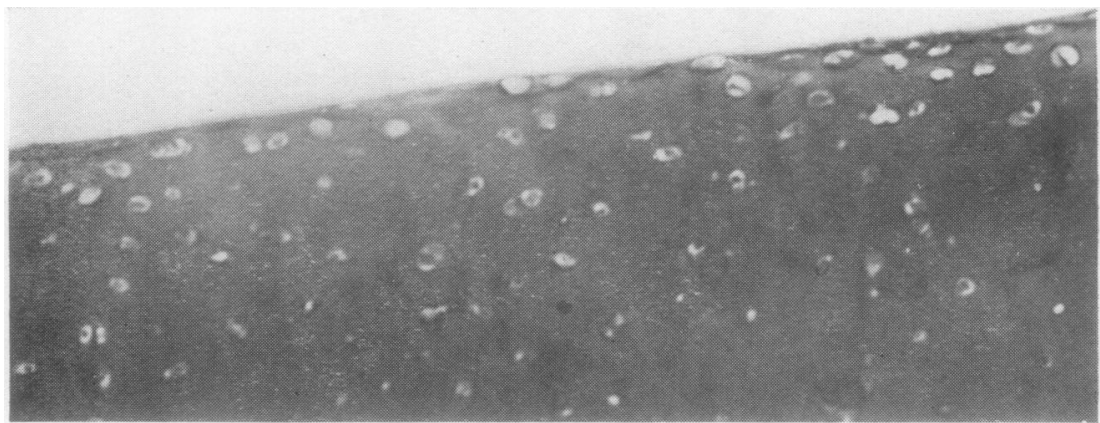

Fig. 1.-Toluidine blue preparation of a juvenile sample of articular cartilage from the upper end of the humerus. Note that the matrix staining extends to the articular surface. Female aged 8 years. $\times 125$.

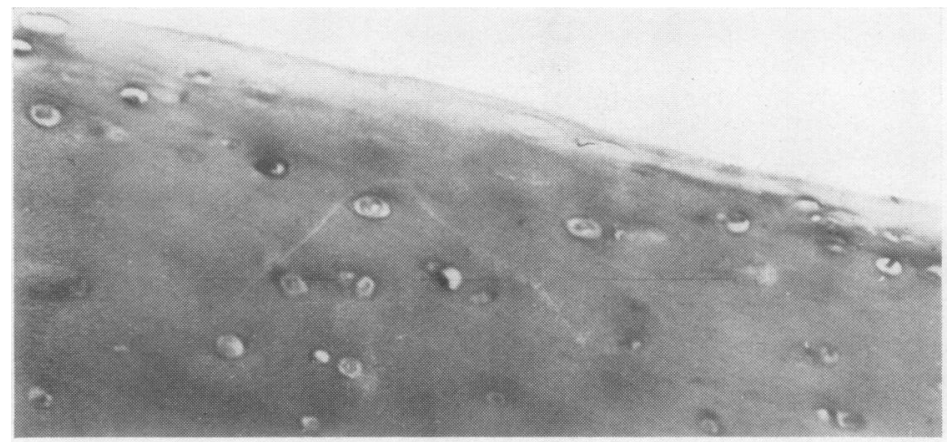

Fig. 2.-Toluidine blue preparation of an adult cartilage sample from the upper end of humerus. Note the narrow band of absent matrix staining immediately beneath the nonfibrillated articular surface, and note also the empty lacunae and loss of nuclei in this region. Male aged 74 years. $\times 125$.

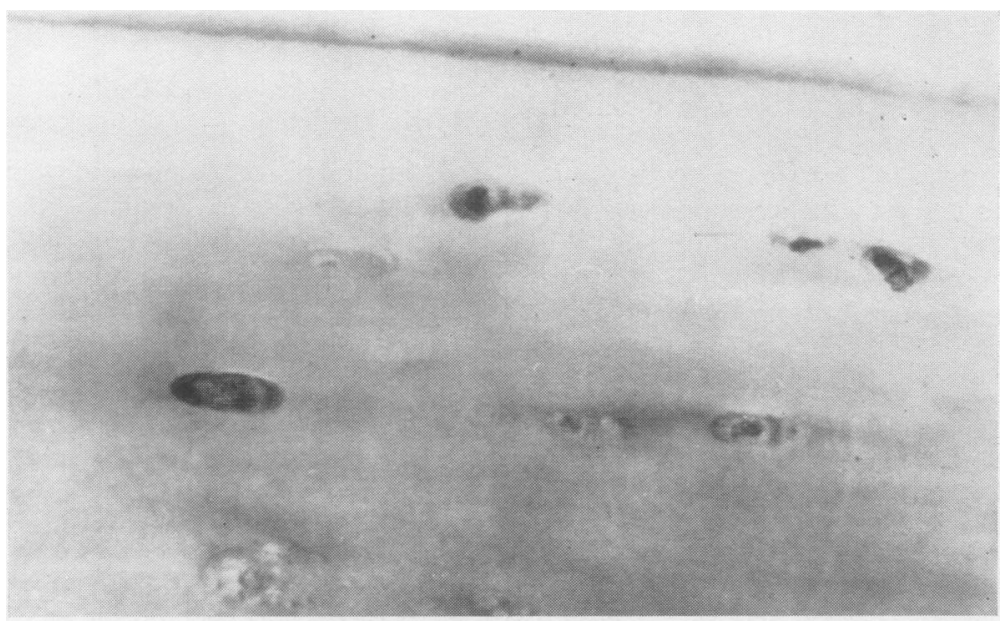

Fig. 3.-Toluidine blue preparation of a non-fibrillated area of femoral articular cartilage. Matrix depletion extends deeply into the superficial layer and there is fairly extensive loss of stainable nuclei. No cells with metachromatic rimming are seen in the matrix-depleted region. Male aged 58 years.

$$
\times 310 \text {. }
$$


immediately beneath the articular surface (Fig. 2), and sometimes this band of pale staining is interrupted by areas of metachromasia reaching almost to the surface. In its advanced form, matrix depletion extends deeply into the superficial layer of non-fibrillated areas (Fig. 3); areas with this advanced change include those immediately adjacent to fibrillated sites.

Non-fibrillated regions of matrix depletion have been searched for cells showing metachromatic rimming in toluidine blue preparations. Moderate numbers of rimmed cells are seen in some of the areas examined (Figs 4 and 5) but in many other areas such cells are few in number or virtually absent (Fig. 3).

\section{Nuclear Degeneration}

Often, in non-fibrillated regions of matrix depletion, a variable number of the cells show nuclear degeneration, as evidenced by alteration or loss of nuclear staining in toluidine blue or haematoxylin preparations (Figs 2, 3, and 6). In areas showing a limited degree of matrix depletion, nuclear loss, when present, is restricted to some of those chondrocytes which lie just beneath the articular surface (Fig. 2); in areas showing a more advanced form of matrix depletion, nuclear degeneration is seen at deeper levels of the superficial layer of cartilage (Fig. 3). Clear or empty lacunae are often seen (Figs 2 and 6). Some of these occupy an area corresponding to a cell or pair of cells (Fig. 2);

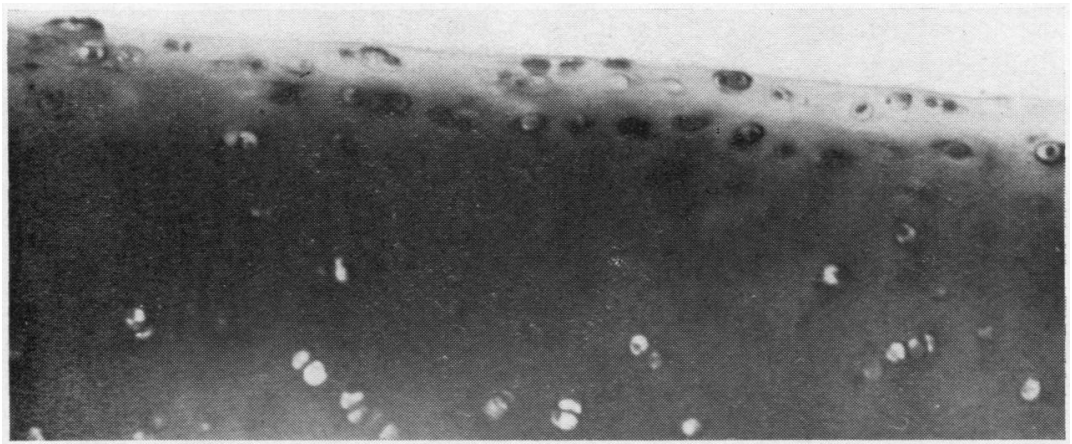

Fig. 4--Toluidine blue preparation of a non-fibrillated area of adult articular cartilage. Note the band of absent matrix staining below the intact surface. Some of the cel!s in the band of matrix depletion show metachromatic rimming. Upper end of humerus; male aged 59 years. $\times 125$.

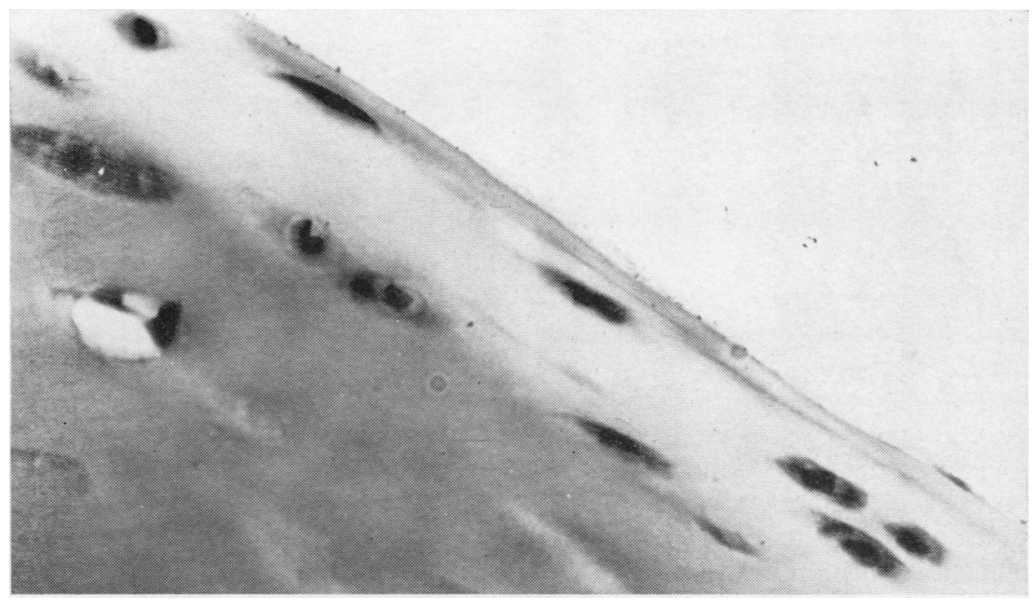

Fig. 5.-Toluidine blue preparation of a non-fibrillated area of adult femoral articular cartilage. A moderate number of rimmed cells are seen in the region of matrix depletion. Male aged 59 years. $\times 310$. 
occasionally much larger lacunae are seen (Fig. 6). Meachim and Collins (1962) suggested that the clear lacunae probably mark the site of effete cells. Evidence in support of this view has now been obtained in electron micrograph of a lacuna and its surrounding structure in the superficial layer of a sample of adult human femoral articular cartilage (Fig. 7). This shows a sharply demarcated ovoid lacuna, surrounded by fibrous matrix, towards one end of which there is a degenerate cell and towards the other end a collection of debris possibly derived from a second cell which has completely disintegrated.

\section{Fibrillation}

Areas of superficial fibrillation show matrix depletion and loss of some nuclei extending well into the superficial layer of the cartilage (Fig. 8). In this respect the appearance is comparable to that seen in non-fibrillated areas showing advanced regressive change.

As seen under the light microscope, the early stages of fibrillation are characterized by fraying of the articular surface to form long narrow strands (Fig. 9) and shorter broad-based tufts (Fig. 10). Small pits are also seen in the cartilage surface (Fig. 10). The appearances strongly suggest that at least some of the pits are formed by rupture or erosion of enlarged lacunae.

\section{Comparison of the Knee and Shoulder Joints}

The adult cartilages show some variation of appearances from sample to sample and, to a lesser extent, from area to area within the same sample. Non-fibrillated areas showing some degree of regressive change are common both in cartilage from the head of humerus and from the femoral condyle, but regressive change is usually more advanced in the femoral cartilage, and a much higher proportion of these samples also include areas of osteoarthritic fibrillation.

\section{Discussion}

The present study was suggested by the results of animal experiments previously reported. After various operations on the joint, it was found that rabbit articular cartilage sometimes showed accelerated turnover of sulphated ground substance and slight loss of stainable nuclei in its superficial zone (Meachim, 1964). These changes were observed at a time after operation when the cartilage usually showed no evidence of fibrillation. The findings suggested that an attempt should be made to discover whether any changes precede the onset of osteo-arthritic fibrillation in human cartilage.

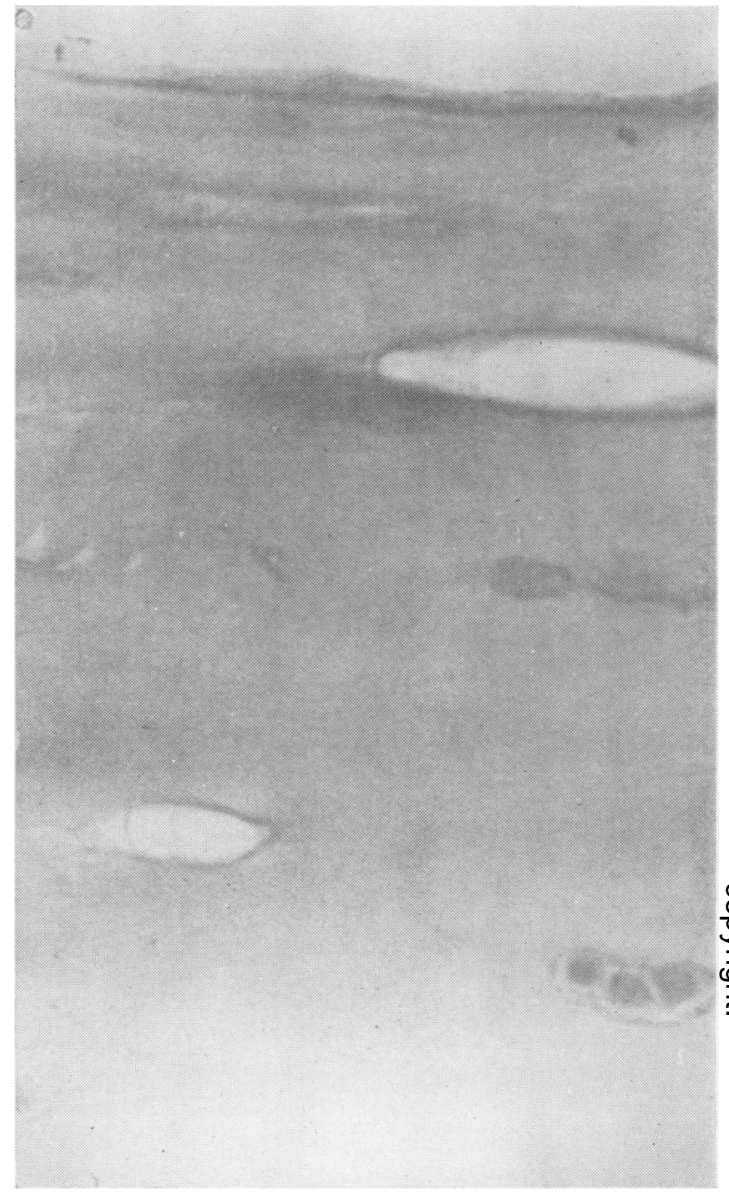

Fig. 6.-Lacunae and extensive nuclear loss in a non-fibrillated area of femoral articular cartilage. Note the large lacuna, and note also (below) a second lacuna, intersected by thin strands of tissue to form compartments each of a similar size to that of a cell. Male aged 74 years. Haematoxylin and eosin $\times 500$.

The observations now presented indicate that changes of a regressive nature can occur in human articular cartilage even in the absence of osteoarthritic fibrillation. In non-fibrillated areas of adult samples, the superficial layer often shows depletion of matrix ground substance and evidence of nuclear degeneration with the formation of clear or empty lacunae thought to mark the site of effete cells. In their least-developed form these features are confined to a narrow band of cartilage lying immediately beneath the articular surface; in their advanced form they extend deeply into the superficial layer.

As seen under the light microscope, early fibrillation is characterized by fraying of the articular surface to form long narrow strands and shorter 


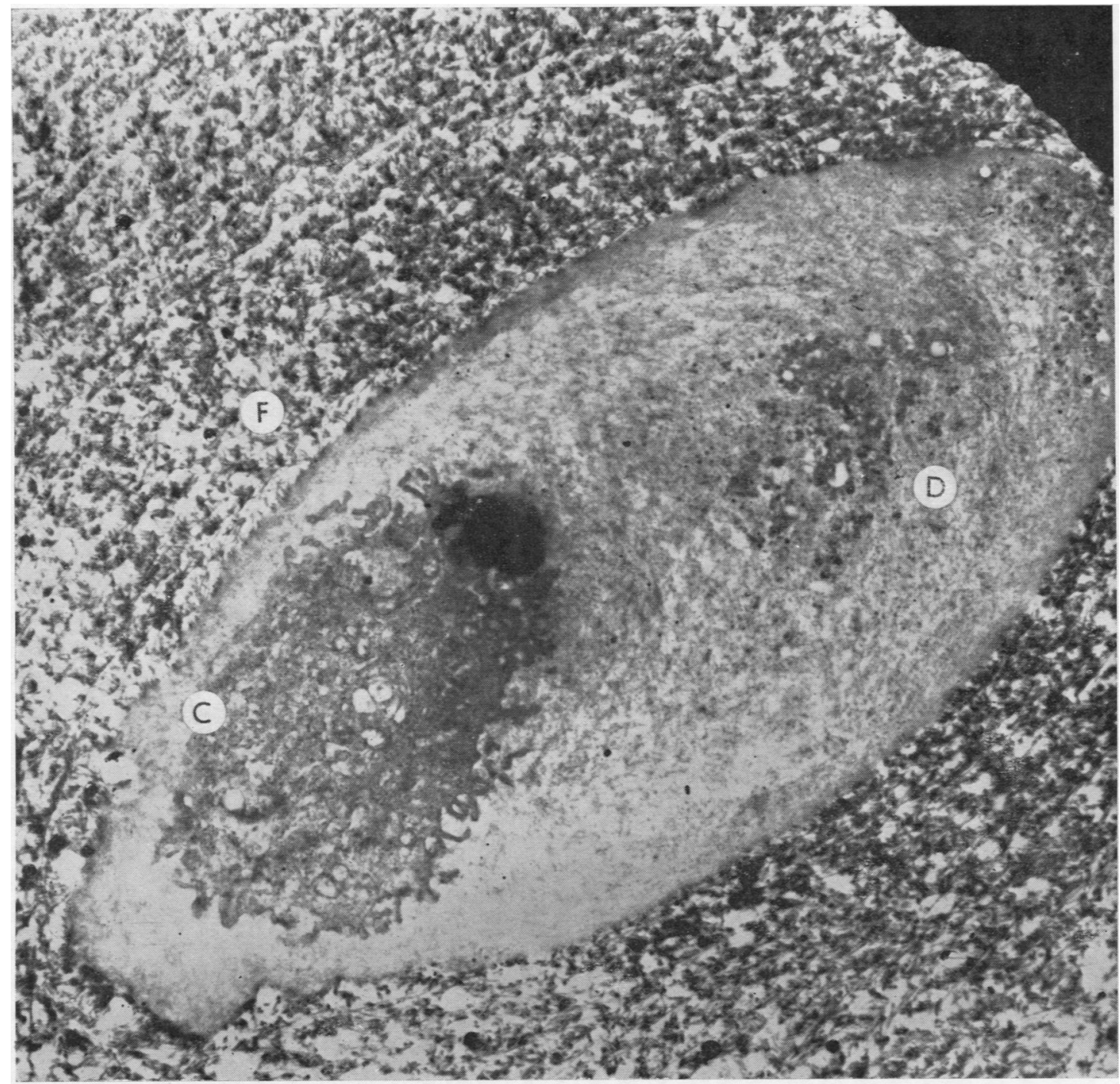

Fig. 7.-Electron micrograph of a lucuna and surrounding structure in the superficial laver of adult human femoral articular cartilage. A sharply demarcated ovoid lacuna is surrounded by fibrous matrix $(F)$. Towards one end of this ovoid area there is a degenerate cell (C) with vacuolated cytoplasm. Towards the other end there is a collection of debris (D) possibly derived from a second cell which has completely disintegrated. Female aged 82 years. Uranyl acetate. $\times 7,000$. 


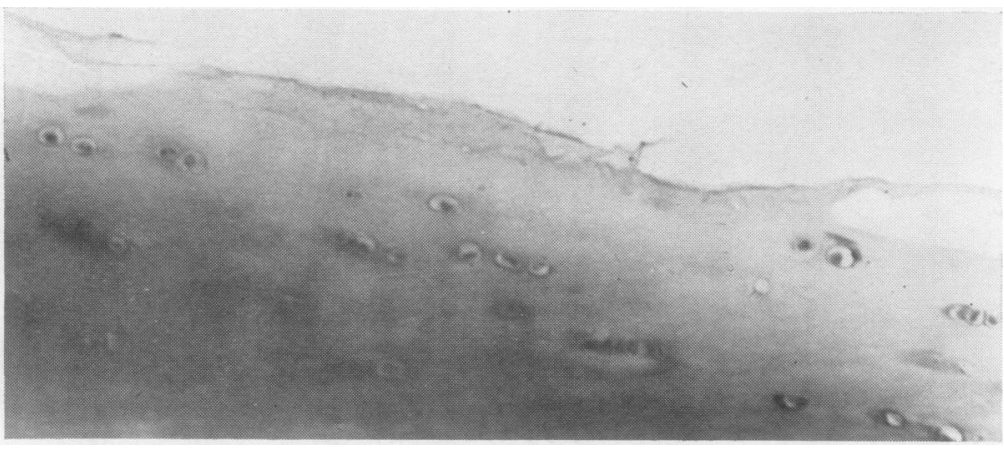

Fig. 8. - Toluidine blue preparation of an area of early fibrillation in femoral articular cartilage. Matrix depletion and loss of stainable nuclei extends well into the superficial layer. Male aged 74 years. $\times 125$.

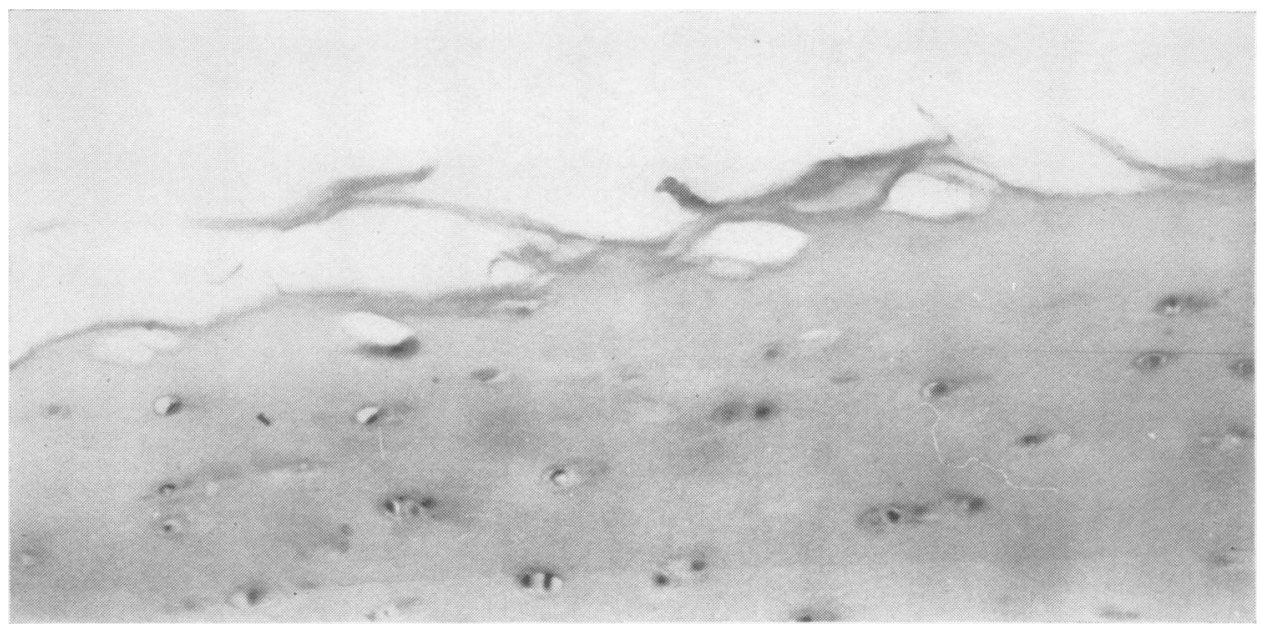

Fig. 9.-Early fibrillation in femoral articular cartilage. Note fraying to form long narrow strands. Note also the enlarged lacunae immediately below the articular surface, and compare with Fig. 10. Male aged 74 years. Haematoxylin and eosin. $\times 125$.

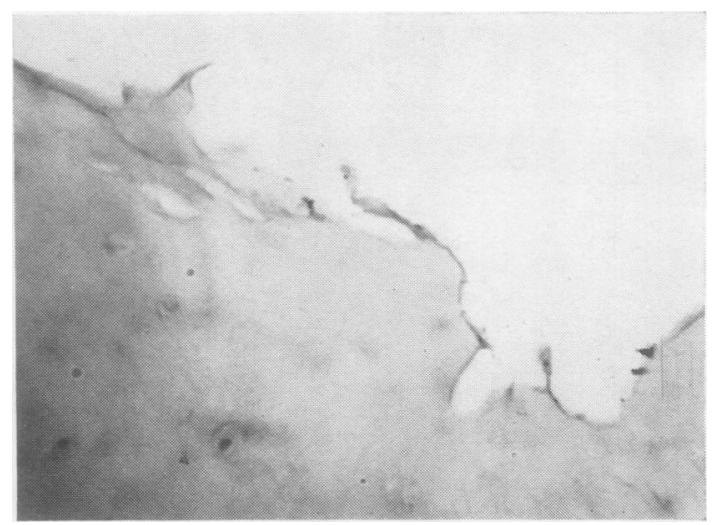

Fig. 10. - Early fibrillation in femoral articular cartilage. Note the fraying and the broad-based tuft at the surface, and note also the small pits in the surface. Male aged 59 years. Toluidine blue

$$
\times 125 \text {. }
$$


broad-based tufts. Small pits are also seen in the cartilage surface, and are probably formed by rupture or erosion of enlarged lacunae. On electron microscopy of rabbit cartilage, Barnett, Cochrane, and Palfrey (1963) have noted that the articular surface in older animals shows increased irregularity and fissures too minute to be visible by the light microscope. It would therefore be helpful to study the surface of human articular cartilage with the electron microscope, to determine whether similar changes also occur in man and to assess their importance in the development of osteo-arthritic fibrillation.

Non-fibrillated areas immediately adjacent to fibrillated sites tend to show an advanced stage of regression, suggesting that osteo-arthritic fibrillation develops as an extension of regressive change. In keeping with this interpretation, it has been found that regression is usually more advanced in samples from the femoral condyle than in samples from the head of the humerus, just as actual osteo-arthritis is more prone to develop in the knee than in the shoulder (Collins, 1949). Regressive changes are common at both sites, but local conditions in the knee joint evidently favour their more rapid development.

Both osteo-arthritic fibrillation and regressive change are accompanied by reduction or loss of matrix staining with toluidine blue, indicative of matrix ground substance depletion. In normal cartilage there is a perpetual biological turnover of chondromucoprotein ground substance, with a continual synthesis of new chondromucoprotein by the cartilage cells and a continual breakdown of chondromucoprotein in the intercellular matrix (Gross, Mathews, and Dorfman, 1960). Collins and McElligott (1960) suggested that the ground substance depletion of osteo-arthritis was due primarily to a fault in the matrix rather than to degeneration of the cells.

In support of their view, Collins and McElligott were able to demonstrate continued synthetic activity by the deeper chondrocytes, and particularly by the cell clusters, in fibrillated areas of matrix depletion; they noted that the cellular activity tended eventually to disappear in tags of cartilage before the tags finally separated from the main cartilage mass. However, a phase of continued synthetic activity has not been noted in the more superficial chondrocytes in fibrillated areas of human cartilage (Collins and McElligott, 1960; Collins and Meachim, 1961). The observations now reported suggested that this apparent discrepancy might be due to the time sequence of the changes. It is possible that cellular activity may persist for a time during regressive matrix depletion, but may cease in the superficial zone before actual fibrillation occurs. Nonfibrillated regions of matrix depletion have therefore been searched for chondrocytes showing metachromatic rimming, since the presence of rimming seems to correlate well with recent metabolic activity (Collins and McElligott, 1960; Meachim, 1963). Moderate numbers of rimmed cells are, in fact, seen in some of the areas examined, but in many other areas such cells are few in number or virtually absent. It would thus appear that cellular degeneration can sometimes lag behind matrix depletion in the superficial layer of the cartilage, but that the continued cellular activity is of a relatively transient nature.

\section{Summary and Conclusions}

A study has been made to determine whether changes of a regressive nature can be detected in the superficial layer of adult human articular cartilage before the onset of osteo-arthritic fibrillation, and also to examine the morphology of superficial fibrillation. Articular cartilage from babies and children was used as a standard against which to compare the degree of change present in adult samples from persons ranging in age from 28 to 82 years. The cartilage samples were collected from the central aspect of the upper end of humerus and from near the edge of a femoral condyle.

Many of the sections from adults include nonfibrillated areas in which the superficial layer shows depletion of matrix ground substance, evidence of nuclear degeneration, and the formation of clear or empty lacunae thought to mark the site of effete cells.

In their least developed form these features are confined to a narrow band of cartilage lying immediately beneath the articular surface; in their advanced form they extend deeply into the superficial layer. Non-fibrillated areas showing some degree of regressive change are common both in adult samples from the upper end of the humerus and from the femoral condyle, but regressive change is usually more advanced in the femoral samples and a much higher proportion of these samples also include areas of actual osteo-arthritic fibrillation. Nonfibrillated areas immediately adjacent to fibrillated sites tend to show an advanced stage of regression. It is suggested that osteo-arthritic fibrillation develops as an extension of regressive change.

As seen under the light microscope, early fibrillation is characterized by fraying of the articular surface to form long narrow strands and shorter broad-based tufts. Small pits are also seen in the cartilage surface, and these appear to be formed by the rupture or erosion of enlarged lacunae. 


\section{REFERENCES}

Barnett, C. H., Cochrane, W., and Palfrey, A. J. (1963). Ann. rheum. Dis., 22, 389.

Bennett, G. A., Waine, H., and Bauer, W. (1942). "Changes in the Knee Joint at Various Ages". Commonwealth Fund, New York.

Collins, D. H. (1949). "The Pathology of Articular and Spinal Diseases", Chap. 5, pp. 74-115. Arnold, London.

__ and McElligott T. F. (1960). Ann. rheum. Dis., 19,318 and Meachim, G. (1961). Ibid., 20, 117.

Gross, J. I., Mathews, M. B., and Dorfman, A. (1960). J. biol. Chem., 235, 2889.

Matthews, B. F. (1953). Brit. med. J., 2, 660.

Meachim, G. (1963). J. Bone Jt Surg., 45-B, 150.

(1964). Ann. rheum. Dis., 23, 372.

and Collins, D. H. (1962). Ibid., 21, 45.

\section{Altérations regressives dans la couche superficielle du cartilage articulaire humain}

\section{RÉSUMÉ}

On étudia la couche superficielle du cartilage humain pour voir si l'on peut y déceler des altérations de nature regressive avant le début de la fibrillation ostéo-arthritique et pour examiner la morphologie de la fibrillation superficielle.

Le cartilage articulaire de nourrissons et d'enfants servit de standard, auquel on compara l'intensité des altérations vus dans le cartilage des adultes dont l'âge s'échelonnait entre 28 et 82 ans. Ce cartilage fut prélevé sur l'aspect central supérieur de l'humerus ou près de l'arête d'un condyle fémoral.

Beaucoup de coupes de cartilage adulte comprennent des zones sans fibrillation, dans lesquelles la couche superficielle est dépourvue de substance matrice fondamentale et accuse des signes de dégénérescence nucléaire et de formation de lacunes claires ou vides indiquant, croit-on, les positions des cellules caduques.

En sa forme primaire, ces caractéristiques se bornent à une bande étroite située directément en dessous de la surface articulaire; en sa forme avancée, elles pénètrent loin dans la couche superficielle. Des zones sans fibrillation avec quelques altérations regressives se trouvent habituellement dans les prélèvements du bout supérieur de l'humérus adulte et dans ceux du condyle fémoral adulte, mais ces altérations regressives sont généralement plus intenses dans les échantillons fémoraux et une plus grande proportion de ces échantillons contient aussi des zones de fibrillation ostéo-arthritique franche.
Des zones non-fibrillées adjacentes aux endroits fibrillés tendent à accuser un état de regression plus intense. On pense que la fibrillation ostéo-arthritique se développe à partir des altérations regressives.

D'après ce qu'on voit sous le microscope lumineux, le début de la fibrillation est caractérisé par l'éraillement de la surface articulaire, ce qui forme des brins longs et étroits et des touffes à base large et plus courtes. On voit aussi dans la surface cartilagineuse de petits trous, créés, semble-t-il, par la rupture et l'érosion menant à l'extension des lacunes.

\section{Alteraciones regresivas en la capa superficial del cartilago articular humano}

\section{SUMARIO}

Se estudió la capa superficial del cartílago humano en busca de alteraciones de naturaleza regresiva antes del comienzo de la fibrillación osteoartrítica y para examinar la morfología de la fibrillación superficial.

El cartílago articular de niños y de infantes sirvió de standard, al que fueron comparadas las alteraciones encontradas en el cartílago de adultos de edades entre 28 y 82 años. Muestras del cartílago estudiado fueron recogidas del aspecto central del cabo superior del húmero o cerca del canto de un cóndilo femoral.

Muchos cortes del cartílago humano incluyen espacios sin fibrillación, en los cuales la capa superficial se ve agotada de substancia matriz fundamental, con evidencia de degeneración nuclear y formación de lacunas claras $o$ vacias que indican probablemente las posiciones de las células desgastadas.

En su forma primaria, estos rasgos se limitan a una faja estrecha situada directamente debajo de la superficie articular; en su forma adelantada, penetran profundamente en la capa superficial. Zonas sin fibrillación, con algunas alteraciones regresivas se hallan generalmente tanto en los cortes del cabo superior del húmero adulto como en los del cóndilo femoral adulto, pero tales alteraciones se ven más adelantadas habitualmente en las muestras femorales y una mayor proporción de éstas contiene también zonas de fibrillación osteoartrítica franca.

Zonas sin fibrillación adyacentes a sitios con fibrillacion tienden a acusar un estado de regresión más pronunciado. Se cree que la fibrillación osteoartrítica se desarrolla en extensión de las alteraciones regresivas.

A juzgar de lo que se ve bajo el microscopio luminoso, el comienzo de la fibrillación se caracteriza por el desgaste de la superficie articular, con formacion de cabos largos y estrechos y de copetes más anchos y más cortos. Se ven también en la superficie cartilaginosa pequeñas cavidades creadas, al parecer, por rotura y erosión de lacunas aumentadas. 